\author{
Remigiusz Żulicki \\ Uniwersytet Łódzki \\ Instytut Socjologii \\ Katedra Socjologii Kultury \\ remigiusz.zulicki@uni.lodz.pl
}

\title{
ZATRUDNIENIE ABSOLWENTÓW TURYSTYKI I REKREACJI UNIWERSYTETU ŁÓDZKIEGO ANALIZA SOCJOLOGICZNA WYNIKÓW BADAŃ SONDAŻOWYCH
}

\begin{abstract}
Abstrakt: Artykuł dotyczy wybranych aspektów ekonomicznych losów absolwentów kierunku „turystyka i rekreacja” Uniwersytetu Łódzkiego. Celem autora jest poszukiwanie odpowiedzi na pytanie: „Od czego zależy status zatrudnienia absolwenta?". Podstawę empiryczną stanowiły wyniki badań sondażowych prowadzonych przez Uniwersytet Łódzki w latach: 2014,2015 i 2016 wśród absolwentów rok po ukończeniu studiów. Porównano losy zawodowe absolwentów turystyki i rekreacji z innymi absolwentami Wydziału Nauk Geograficznych UŁ. Zastosowano model regresji logistycznej w celu przewidywania statusu zatrudnienia absolwenta na podstawie wybranych zmiennych. Uzyskano dokładność przewidywań na poziomie $75 \%$. Najsilniejszymi predyktorami statusu zatrudnienia były charakterystyki strukturalno-instytucjonalne. Wyniki ilościowe zinterpretowano w kontekście współczesnej roli uniwersytetów.
\end{abstract}

Słowa kluczowe: absolwenci, zatrudnienie, uniwersytet, regresja logistyczna.

\section{WSTĘP}

Artykuł dotyczy wybranych aspektów - jak nazywa je Ministerstwo Nauki i Szkolnictwa Wyższego - ekonomicznych losów absolwentów (ela.nauka.gov.pl) turystyki i rekreacji (dalej: TiR) Wydziału Nauk Geograficznych (WNG) Uniwersytetu Łódzkiego. Celem autora artykułu jest znalezienie odpowiedzi na pytanie: "Od czego zależy status zatrudnienia absolwenta?". Ów status zatrudnienia rozumiany jest jako deklaracja absolwenta $\mathrm{w}$ chwili badania: pracuję/nie pracuję. Podstawę empiryczną stanowią wyniki badań sondażowych prowadzonych wśród absolwentów rok po ukończeniu studiów przez Biuro Karier UŁ w latach: 2014, 2015 i 2016. Porównano zawodowe losy absolwentów TiR z losami innych absolwentów WNG UŁ. Wyniki ilościowe zinterpretowano w kontekście współczesnej roli uniwersytetów w przygotowaniu młodych ludzi do rozpoczęcia kariery zawodowej.

\section{PRZEGLĄD LITERATURY}

Potrzebę badań, o jakich tu mowa, dostrzeżono w Polsce już w latach 20. ubiegłego stulecia. Jak podaje L. PAŁASZ $(2004$, s. 5): „Prawdopodobnie po raz pierwszy koncepcję badania losów absolwentów szkół wyższych w Polsce podjął A.B. Dobrowolski w 1923 r." Autor za cel badań stawiał dostosowanie kształcenia do potrzeb ówczesnego rynku pracy, zaś podstawowe pytanie badawcze brzmieć miało: „Czy wychowańcy szkół wyższych naprawdę otrzymali wykształcenie mniej więcej podobne do tego, co naprawdę na swych stanowiskach robią?" (PAŁASZ 2004, s. 5). W początkach lat 50. XX w. tego rodzaju badania podejmowal S. Wołoszyn, zaś w drugiej połowie dekady Zakład Badań Socjologicznych PAN pod kierownictwem J. Szczepańskiego zrealizował pierwsze kompleksowe badanie karier zawodowych absolwentów. Autor opublikował nieco później Socjologiczne zagadnienia 
wyższego wykształcenia, gdzie wskazał podstawę teoretyczną i metody badań losów absolwentów (SZCZEPAŃSKI 1963). Wprowadził tam terminy „funkcja założona" i "funkcja rzeczywista” uniwersytetu. Pierwszą z wymienionych należy łączyć z ideą podstawową uniwersytetu, rozumianą jako wartości sformalizowane w statucie. Funkcja czy funkcje rzeczywiste to takie, jakie powinien spełniać uniwersytet w odpowiedzi na zapotrzebowanie społeczne (SZCZEPAŃSKI 1963, s. 16-18). Zatem niniejszy artykuł poświęcony jest badaniom funkcji rzeczywistej.

Kierunek studiów "turystyka i rekreacja" powołano w Polsce w latach 70. minionego wieku na kilku Akademiach Wychowania Fizycznego; obecnie na tym kierunku kształcą zarówno wyższe szkoły niepubliczne, jak i uniwersytety (LISZEWSKI 2010). Autorzy raportu z ostatniego ogólnopolskiego badania na temat "Losy absolwentów szkół i uczelni kształcących kadry dla turystyki", zrealizowanego na zamówienie Ministerstwa Sportu i Turystyki, zwracają uwagę na turystykę jako jedną z najszybciej rozwijających się i najbardziej rentownych gałęzi gospodarki (ZARZECKI $i$ in. 2010). $\mathrm{W}$ raporcie zaprezentowano proste podsumowania zebranych danych - tabele i wykresy, rzadko przedstawiano statystyki opisowe. Zaletą omawianego badania jest zastosowany losowy dobór próby (PPS - Probability Proportional to Size) $n=500$ (dla absolwentów szkół wyższych) zgodny z metodologią GUS (ZARZECKI $i$ in. 2010, s. 19). W opracowaniu brakuje jednak statystycznego testowania hipotez i modelowania zależności. Znacznie bardziej zaawansowaną statystycznie i merytorycznie praca jest Przechodzenie absolwentów studiów geograficznych na rynek pracy. Proces, czynniki, predykcja (PIRÓG 2015). Autorka za cel pracy postawiła „wyjaśnienie uwarunkowań, mechanizmów, przebiegu i determinacji procesu tranzycji absolwentów uczelni wyższych w Polsce na przykładzie absolwentów kierunku geografia" (PIRÓG 2015, s. 26). Tranzycja rozumiana jest tu jako „przechodzenie absolwentów poszczególnych szczebli edukacji do zatrudnienia" (PIRÓG 2015, s. 26). Dwuetapowe badanie na próbie 1120 ochotników z 12 polskich uczelni objęło także absolwentów specjalności z zakresu turystyki - stanowili oni około 10\% badanych (PIRÓG 2015, s. 94). Modelowanie techniką analizy dyskryminacyjnej krokowej wykonano dla $n=375$; były to osoby badane pół roku po ukończeniu studiów. Zmienną zależną był status zatrudnienia absolwenta rozpatrywany w kategoriach "pracujący/niepracujący” (PIRÓG 2015 , s. 145). Niestety badaniem objęto wyłącznie absolwentów studiów stacjonarnych (PIRÓG 2015, s. 32), co z uwagi na uzyskane $\mathrm{w}$ niniejszym artykule wyniki prowadzi do niepełnej porównywalności uzyskanych modeli - tryb studiów okazał się jednym z istotnych predyktorów statusu zatrudnienia absolwenta WNG UŁ (por. rozdz. 7: „Model statusu zatrudnienia absol- wentów"). Niemniej porównanie dopasowania modeli - zaproponowanego tu i w książce D. PIRÓG (2015) - będzie przedstawione w dalszej części niniejszej pracy z uwagi na walory poznawcze.

\section{METODY I TECHNIKA BADAWCZA}

Materiał badawczy został zebrany i udostępniony przez Biuro Karier Uniwersytetu Łódzkiego w ramach „Monitorowania karier zawodowych absolwentów UŁ" (http:/ / biurokarier.uni.lodz.pl). Jest to cykliczne badanie panelowe, prowadzone na potrzeby władz uczelni i jej Wydziałów. Analizowane w artykule badania wykonywano rok po ukończeniu studiów dla każdego rocznika absolwentów uczelni: 2012/2013, 2013/2014 i 2014/2015. Jest to pierwsza tura badania. Jako moment zakończenia edukacji przyjmuje się tutaj rok akademicki, w którym złożono ostatni egzamin przed obroną pracy dyplomowej. Badania mają charakter ogólnouczelniany, obejmują absolwentów wszystkich 12 wydziałów uczelni w Łodzi i filii w Tomaszowie Mazowieckim, wszystkich trybów (studia stacjonarne i niestacjonarne) oraz rodzajów studiów (licencjackie, uzupełniające magisterskie i jednolite magisterskie), kończących studia $\mathrm{w}$ danym $\mathrm{w}$ roku akademickim.

Zastosowano ankietę internetową CAWI (Computer Assisted Web Interview), zaimplementowaną w serwisie Lime Survey. Odpowiedzi zbierane są corocznie od kwietnia do czerwca. Zakres badań dotyczy:

1) charakterystyki społeczno-demograficznej badanych,

2) rodzaju, trybu, wydziału i kierunku ukończonych studiów,

3) dodatkowej aktywności podejmowanej w trakcie zdobywania wyższego wykształcenia,

4) aktualnego zatrudnienia absolwentów,

5) sytuacji absolwentów niepracujących,

6) dalszych planów zawodowych i edukacyjnych absolwentów,

7) oceny studiów na Uniwersytecie Łódzkim.

Kwestionariusz składa się z 69 pytań. Z uwagi na cel i zakres przedmiotowego artykułu pominięto całkowicie problematykę ujętą w punktach 5,6 i 7 .

Zastosowane w kolejnych latach ankiety są spójne i ulegały niewielkim zmianom, dzięki czemu możliwe było połączenie odpowiedzi udzielonych przez absolwentów różnych roczników. Wszystkie przekształcenia (odfiltrowanie rekordów absolwentów WNG z pełnych arkuszy kolejnych roczników badania ogólnouczelnianego, połączenie danych $\mathrm{z}$ trzech roczników w jeden arkusz, rekodowanie zmiennych), analizy (testy statystyczne i model regresji logistycznej) oraz podsumowania danych (tabele i wykresy) wy- 
konano za pomoca programu IBM SPSS Statistics 24.0.0.0. Przyjęto typowy dla nauk społecznych poziom istotności $\alpha=0,05$.

\section{CHARAKTERYSTYKA BADANEJ GRUPY}

Kwestionariusz wysyłany jest mailowo wyłącznie do osób, które zdając w dziekanacie kierunkowym kartę obiegową wyraziły zgodę na udział w badaniu karier zawodowych. W omawianych latach realizacji badania - 2014, 2015, 2016 - uzyskano odpowiednio 1545, 1023 i 1491 odpowiedzi (tab. 1).

Tab. 1. Realizacja badania karier zawodowych absolwentów Uniwersytetu Łódzkiego (I tury) w latach 2014-2016

\begin{tabular}{|l|c|c|c|}
\hline \multirow{2}{*}{\multicolumn{1}{c|}{ Wyszczególnienie }} & \multicolumn{3}{c|}{ Rok realizacji badania } \\
\cline { 2 - 4 } & 2014 & 2015 & 2016 \\
\hline Rocznik absolwentów & $2012 / 13$ & $2013 / 14$ & $2014 / 15$ \\
\hline Populacja absolwentów UŁ $(N)$ & 9844 & 9631 & 9844 \\
\hline Zgody na udział w badaniu $(N)$ & 4109 & 3396 & 3775 \\
\hline Próba zrealizowana $(N)$ & 1545 & 1023 & 1491 \\
\hline Zgody/Populacja (\%) & 41,7 & 35,3 & 41,4 \\
\hline Próba/Populacja (\%) & 15,7 & 10,6 & 16,4 \\
\hline Próba/Zgody (\%) & 37,6 & 30,1 & 39,5 \\
\hline
\end{tabular}

Źródło: Biuro Karier Uniwersytetu Łódzkiego.

W badaniu wzięło zatem udział od około $11 \%$ (rocznik 2013/2014) do 16\% (pozostałe roczniki) populacji absolwentów w danym roczniku. Próby te nie są reprezentatywne, choć dla całej uczelni struktura płci, rodzaju i trybu studiów badanych jest zbliżona do rozkładu tych cech w populacji. Ponadto dysponowano próbą złożoną z ochotników, co zawsze skutkuje nieznanym obciążeniem wyników. Typowym przykładem takiej sytuacji jest przeprowadzone $\mathrm{w}$ latach 50. ubiegłego stulecia amerykańskie badanie ankietowe zachowań seksualnych na próbie ochotników. Późniejsze badania wykazały, że odpowiedzi częściej udzielały osoby ponadprzeciętnie aktywne seksualnie (BRZEZIŃSKI 2003, s. 232). Być może w przypadku monitorowania karier absolwentów respondenci są silniej związani emocjonalnie z uczelnią niż osoby, które nie wyraziły zgody na udział w badaniu bądź zgodę wyraziły, ale później nie odpowiedziały na zaproszenie do udziału w badaniu.

$\mathrm{Na}$ potrzeby tego opracowania grupę badanych ograniczono do absolwentów WNG. Łącznie jest to 340 osób. W przypadku dziewięciu respondentów wystąpiły pozycyjne braki danych (item nonresponse), zatem pełne odpowiedzi uzyskano od 331 osób. W obu badaniach brało udział 19 respondentów - jako absolwenci studiów I stopnia rocznika 2012/2013 i II stop- nia rocznika 2014/2015. Każdą taką osobę potraktowano jako dwie niezależne jednostki analizy, ponieważ $\mathrm{w}$ niniejszym artykule nie podjęto porównania grup zależnych według czasu. $\mathrm{W}$ tab. 2 przedstawiono badaną grupę $\mathrm{w}$ podziale na kierunki studiów. O ile nie zaznaczono inaczej, w tabelach ukazano udzial $\mathrm{w}$ profilach kolumnowych.

Tab. 2. Badani absolwenci Wydziału Nauk Geograficznych UŁ według wszystkich kierunków studiów

\begin{tabular}{|l|r|r|}
\hline \multicolumn{1}{|c|}{ Kierunek studiów } & $\begin{array}{c}\text { Liczba } \\
\text { absol- } \\
\text { wentów }\end{array}$ & $\begin{array}{c}\text { Udział } \\
\text { procen- } \\
\text { towy }\end{array}$ \\
\hline Geografia & 92 & 27,1 \\
\hline $\begin{array}{l}\text { Geografia nauczycielska w zakresie } \\
\text { geografii i przyrody }\end{array}$ & 38 & 11,2 \\
\hline Geografia, specjalizacja geomonitoring & 21 & 6,2 \\
\hline Geoinformacja & 2 & 0,6 \\
\hline Gospodarka przestrzenna & 99 & 29,1 \\
\hline Studia regionalne & 6 & 1,8 \\
\hline Turystyka i rekreacja & 78 & 22,9 \\
\hline Ekofizjografia z geoekologią & 2 & 0,6 \\
\hline Geografia urbanistyczna & 1 & 0,3 \\
\hline Klimatologia i ochrona atmosfery & 1 & 0,3 \\
\hline Ogółem & 340 & 100,0 \\
\hline
\end{tabular}

Źródło danych do tab. 2-14: opracowanie własne na podstawie "Monitorowania karier zawodowych absolwentów Uniwersytetu Łódzkiego" (http:// biurokarier.uni.lodz.pl).

Absolwenci TiR stanowili trzecią najliczniejszą grupę ankietowanych $(n=78)$. W dalszych przekrojach wszystkie pozostałe kierunki studiów zgrupowano w kategorii ,inny".

W każdym z omawianych roczników absolwenci TiR stanowili nieco ponad $20 \%$ grupy badanej (tab. 3).

Tab. 3. Liczebność kierunków Wydziału Nauk Geograficznych UŁ według roczników badanych absolwentów

\begin{tabular}{|l|c|c|c|c|c|c|c|c|}
\hline \multirow{2}{*}{$\begin{array}{c}\text { Kierunek } \\
\text { studiów }\end{array}$} & \multicolumn{6}{|c|}{ Rocznik } & \multicolumn{2}{|c|}{ Ogółem } \\
\cline { 2 - 9 } & $2012 / 2013$ & $2013 / 2014$ & $2014 / 2015$ & \multicolumn{1}{c|}{$N$} & $\%$ \\
\cline { 2 - 9 } & $N$ & $\%$ & $N$ & $\%$ & $N$ & $\%$ & $N$ & $\%$ \\
\hline Inny & 85 & 78,7 & 79 & 76,0 & 98 & 76,6 & 262 & 77,1 \\
\hline $\begin{array}{l}\text { Turystyka } \\
\text { i rekreacja }\end{array}$ & 23 & 21,3 & 25 & 24,0 & 30 & 23,4 & 78 & 22,9 \\
\hline Ogółem & 108 & 100,0 & 104 & 100,0 & 128 & 100,0 & 340 & 100,0 \\
\hline
\end{tabular}

Ogółem absolwenci studiów niestacjonarnych to prawie 1/10 kończących WNG. W przypadku absolwentów TiR studiujących zaocznie było relatywnie dwa razy więcej (tab. 4).

$\mathrm{W}$ podziale na rodzaj studiów struktura respondentów była zbliżona tak dla WNG, TiR i innych kierunków. Absolwenci studiów licencjackich to nieco ponad $1 / 3$ każdej z grup (tab. 5). 
Tab. 4. Tryb studiów absolwentów WNG UŁ z uwzględnieniem kierunku studiów

\begin{tabular}{|l|r|r|r|r|r|r|}
\hline \multirow{2}{*}{ Tryb studiów } & \multicolumn{2}{|c|}{$\begin{array}{c}\text { Inny } \\
\text { kierunek }\end{array}$} & \multicolumn{2}{c|}{$\begin{array}{l}\text { Turystyka } \\
\text { i rekreacja }\end{array}$} & \multicolumn{2}{c|}{ Ogółem } \\
\cline { 2 - 7 } & \multicolumn{1}{|c|}{$N$} & \multicolumn{1}{c|}{$N$} & $N$ & \multicolumn{1}{c|}{$\%$} & \multicolumn{1}{c|}{$N$} & \multicolumn{1}{c|}{$\%$} \\
\hline Stacjonarne & 244 & 93,1 & 63 & 80,8 & 307 & 90,3 \\
\hline Niestacjonarne & 18 & 6,9 & 15 & 19,2 & 33 & 9,7 \\
\hline Ogółem & 262 & 100,0 & 78 & 100,0 & 340 & 100,0 \\
\hline
\end{tabular}

Tab. 5. Rodzaj studiów absolwentów WNG UŁ $\mathrm{z}$ uwzględnieniem kierunku studiów

\begin{tabular}{|l|c|c|c|c|c|c|}
\hline \multirow{2}{*}{$\begin{array}{c}\text { Rodzaj } \\
\text { studiów }\end{array}$} & \multicolumn{2}{|c|}{$\begin{array}{c}\text { Inny } \\
\text { kierunek }\end{array}$} & \multicolumn{2}{c|}{$\begin{array}{c}\text { Turystyka } \\
\text { i rekreacja }\end{array}$} & \multicolumn{2}{c|}{ Ogółem } \\
\cline { 2 - 7 } & $N$ & $\%$ & $N$ & $\%$ & $N$ & $\%$ \\
\hline I stopnia & 90 & 34,4 & 30 & 38,5 & 120 & 35,3 \\
\hline II stopnia & 172 & 65,6 & 48 & 61,5 & 220 & 64,7 \\
\hline Ogółem & 262 & 100,0 & 78 & 100,0 & 340 & 100,0 \\
\hline
\end{tabular}

Mniej niż 2\% badanych w rok po ukończeniu studiów mieszkało poza Polską (tab. 6). Absolwenci TiR opuszczali kraj nieco częściej niż kończący inne kierunki na WNG. Respondenci wskazywali wyłącznie pojedyncze kraje Europy Północnej.

Tab. 6. Kraj zamieszkania absolwentów WNG UŁ według kierunku studiów

\begin{tabular}{|l|r|r|r|r|r|r|}
\hline \multirow{3}{*}{ Kraj zamieszkania } & \multicolumn{2}{|c|}{$\begin{array}{c}\text { Inny } \\
\text { kierunek }\end{array}$} & \multicolumn{2}{c|}{$\begin{array}{c}\text { Turystyka } \\
\text { i rekreacja }\end{array}$} & \multicolumn{2}{c|}{ Ogółem } \\
\cline { 2 - 7 } & \multicolumn{1}{c|}{$N$} & \multicolumn{1}{c|}{$\%$} & $N$ & \multicolumn{1}{c|}{$\%$} & \multicolumn{1}{c|}{$N$} & \multicolumn{1}{c|}{$\%$} \\
\hline Polska & 259 & 98,9 & 75 & 96,2 & 334 & 98,2 \\
\hline Europa Północna & 3 & 1,1 & 3 & 3,8 & 6 & 1,8 \\
\hline Ogółem & 262 & 100,0 & 78 & 100,0 & 340 & 100,0 \\
\hline
\end{tabular}

W chwili badania poza województwem łódzkim mieszkało około 9,5\% respondentów. Odsetek był nieznacznie wyższy dla absolwentów TiR (tab. 7).

Tab. 7. Województwo, w którym zamieszkali absolwenci WNG UŁ według kierunku studiów

\begin{tabular}{|l|r|r|r|r|r|r|}
\hline \multirow{3}{*}{ Województwo } & \multicolumn{2}{|c|}{$\begin{array}{c}\text { Inny } \\
\text { kierunek }\end{array}$} & \multicolumn{2}{c|}{$\begin{array}{c}\text { Turystyka } \\
\text { i rekreacja }\end{array}$} & \multicolumn{2}{c|}{ Ogółem } \\
\cline { 2 - 7 } & \multicolumn{1}{c}{$\begin{array}{c}\% \\
\text { r }\end{array}$} & \multicolumn{1}{c|}{$N$} & \multicolumn{1}{c|}{$N$} & \multicolumn{1}{c|}{$\%$} \\
\hline Łódzkie & 234 & 89,7 & 65 & 85,5 & 299 & 88,7 \\
\hline Inne województwo & 24 & 9,2 & 8 & 10,5 & 32 & 9,5 \\
\hline Nie mieszka w Polsce & 3 & 1,1 & 3 & 3,9 & 6 & 1,8 \\
\hline Ogółem & 261 & 100,0 & 76 & 100,0 & 337 & 100,0 \\
\hline
\end{tabular}

Jeżeli chodzi o wielkość miejscowości zamieszkania badanych, widać wyraźną różnicę między absolwentami TiR i innych kierunków. Ci pierwsi znacznie częściej deklarowali, że mieszkają w miastach liczących powyżej pół miliona mieszkańców: było to około 68,5\% kończących TiR przy 44,6\% absolwentów innych kierunków (tab. 8).
Tab. 8. Wielkość jednostki osadniczej, w której zamieszkali absolwenci WNG UŁ z uwzględnieniem kierunku studiów

\begin{tabular}{|c|c|c|c|c|c|c|}
\hline \multirow{2}{*}{$\begin{array}{c}\text { Wielkość jednostki } \\
\text { osadniczej } \\
\text { zamieszkania }\end{array}$} & \multicolumn{2}{|c|}{$\begin{array}{c}\text { Inny } \\
\text { kierunek }\end{array}$} & \multicolumn{2}{|c|}{$\begin{array}{l}\text { Turystyka } \\
\text { i rekreacja }\end{array}$} & \multicolumn{2}{|c|}{ Ogółem } \\
\hline & $N$ & $\%$ & $N$ & $\%$ & $N$ & $\%$ \\
\hline Wieś & 68 & 26,4 & 13 & 17,8 & 81 & 24,5 \\
\hline $\begin{array}{l}\text { Miasto z liczbą } \\
\text { mieszkańców: }\end{array}$ & & & & & & \\
\hline - do 10 tys. & 12 & 4,7 & 1 & 1,4 & 13 & 3,9 \\
\hline - od 10 do 100 tys. & 53 & 20,5 & 9 & 12,3 & 62 & 18,7 \\
\hline - od 100 do 500 tys. & 10 & 3,9 & - & - & 10 & 3,0 \\
\hline - powyżej 500 tys. & 115 & 44,6 & 50 & 68,5 & 165 & 49,8 \\
\hline Ogółem & 258 & 100,0 & 73 & 100,0 & 331 & 100,0 \\
\hline
\end{tabular}

Absolwent TiR okazuje się kobietą nieco częściej niż w przypadku innych kierunków studiów na WNG UŁ. Absolwentki stanowią prawie $3 / 4$ badanej grupy (tab. 9).

Tab. 9. Płeć absolwentów WNG UŁ z uwzględnieniem kierunku studiów

\begin{tabular}{|l|r|r|c|r|r|r|}
\hline \multirow{2}{*}{ Płeć } & \multicolumn{2}{|c|}{ Inny } & \multicolumn{2}{c|}{$\begin{array}{l}\text { Turystyka } \\
\text { i rekreacja }\end{array}$} & \multicolumn{2}{c|}{ Ogółem } \\
\cline { 2 - 7 } & $N$ & \multicolumn{1}{c|}{$\%$} & $N$ & $\%$ & $N$ & $\%$ \\
\hline Kobieta & 186 & 71,0 & 65 & 83,3 & 251 & 73,8 \\
\hline Mężczyzna & 76 & 29,0 & 13 & 16,7 & 89 & 26,2 \\
\hline Ogółem & 262 & 100,0 & 78 & 100,0 & 340 & 100,0 \\
\hline
\end{tabular}

\section{AKTYWNOŚĆ PODEJMOWANA W CZASIE STUDIÓW}

Dość powszechne wydaje się przekonanie, że rozmaite dodatkowe formy aktywności studenta pomagają mu lepiej przygotować się do wejścia na rynek pracy. $\mathrm{Na}$ popularnych portalach z ofertami pracy łatwo znaleźć porady w rodzaju: „Tytuł mgr nie robi na pracodawcach już wielkiego wrażenia. Za to aktywność, jeszcze przed podjęciem pierwszej pracy, potrafi podnieść nasze notowania. Udział $\mathrm{w}$ praktykach $\mathrm{i}$ stażach to okazja, żeby wyjść poza uczelnianą teorię i sprawdzić, jak funkcjonuje biznes, jak zdobytą wiedzę akademicką można wykorzystać do realizacji praktycznych projektów i zastosować w codziennej pracy"(https:// kariera.pracuj.pl). Z uwagi na to przyjrzano się skali dodatkowej aktywności respondentów i temu, gdzie podczas studiów udzielali się. Na rys. 1 przedstawiono skalę podejmowania jakichkolwiek $\mathrm{z}$ sześciu wyróżnionych w badaniu form aktywności.

Trudno mówić o różnicach w skali podejmowania różnych form aktywności $\mathrm{w}$ prezentowanym podziale: w każdym przypadku około $42-46 \%$ respondentów deklarowało dodatkowe zajęcie, o którym mowa. Studentów TiR od studiujących na innych kierunkach odróżnia raczej to, jakie rodzaje aktywności podejmo- 


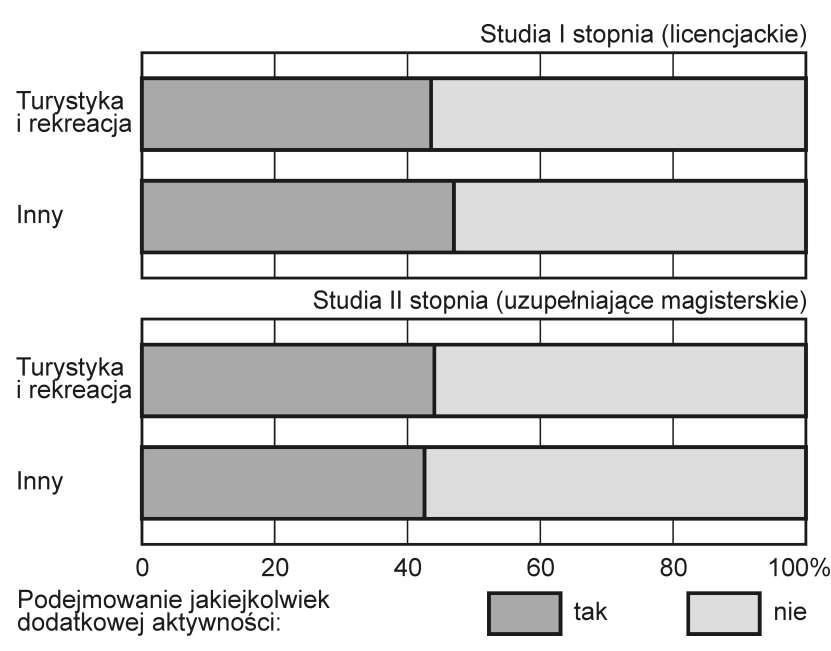

Rys. 1. Podejmowanie dodatkowej formy aktywności podczas studiów z uwzględnieniem kierunku i rodzaju studiów absolwentów WNG UŁ

Źródło danych do rys. 1-8: opracowanie własne na podstawie „Monitorowanie karier zawodowych absolwentów Uniwersytetu Łódzkiego"

wali. Liczebność odpowiedzi z dokładnym wskazaniem rodzaju innej, poza studiowaniem, działalności ukazano w tab. 10.

Tab. 10. Dodatkowe formy aktywności absolwentów WNG UŁ podczas studiów z uwzględnieniem kierunku studiów ${ }^{a}$

\begin{tabular}{|l|c|c|c|c|c|c|}
\hline $\begin{array}{l}\text { Dodatkowe formy } \\
\text { aktywności } \\
\text { podczas studiów }\end{array}$ & \multicolumn{2}{|c|}{ Inny } & \multicolumn{2}{c|}{$\begin{array}{c}\text { Turystyka } \\
\text { i rekreacja }\end{array}$} & \multicolumn{2}{c|}{ Ogółem } \\
\cline { 2 - 7 } & $N$ & $\%$ & $N$ & $\%$ & $N$ & $\%$ \\
\hline $\begin{array}{l}\text { Praktyki } \\
\text { nieobligatoryjne }\end{array}$ & 40 & 34,8 & 7 & 20,6 & 47 & 31,5 \\
\hline Staż & 13 & 11,3 & 6 & 17,6 & 19 & 12,8 \\
\hline Wolontariat & 43 & 37,4 & 12 & 35,3 & 55 & 36,9 \\
\hline $\begin{array}{l}\text { Organizacje } \\
\text { studenckie }\end{array}$ & 15 & 13,0 & 5 & 14,7 & 20 & 13,4 \\
\hline Koła naukowe & 37 & 32,2 & 7 & 20,6 & 44 & 29,5 \\
\hline $\begin{array}{l}\text { Programy wymia- } \\
\text { ny studenckiej }\end{array}$ & 17 & 14,8 & 14 & 41,2 & 31 & 20,8 \\
\hline Ogółem & 115 & 100,0 & 34 & 100,0 & 149 & 100,0 \\
\hline
\end{tabular}

Objaśnienie: ${ }^{a}$ - Odpowiedzi zebrano za pomocą pytania wielokrotnego wyboru.

Badani absolwenci TiR częściej korzystali z programów wymiany studenckiej, zaś rzadziej z praktyk nieobligatoryjnych i działalności w kołach naukowych. $Z$ uwagi na małą liczebność ankietowanych $(n=34$ dla TiR) należy te różnice traktować ostrożnie.

Kolejnym zagadnieniem dotyczącym dodatkowej aktywności studentów jest praca zarobkowa. Wcześnie zdobyte doświadczenie zawodowe uznawane bywa za ważny czynnik sukcesu na rynku pracy. W przywołanym wcześniej artykule kilka wersów dalej napisano: „Im szybciej zaczniemy zdobywać doświadcze- nie zawodowe, tym szybciej się usamodzielnimy i poczujemy pewniej na rynku pracy."(https:// kariera. pracuj.pl). Z drugiej strony można dyskutować o tym, czy każdy rodzaj podejmowanej przez studenta pracy będzie doświadczeniem wartościowym dla jego przyszłej kariery. Wyniki analizy przedstawionej w rozdz. 7: „Model statusu zatrudnienia absolwentów" wskazują na to, że rodzaj zatrudnienia studenta ma istotny statystycznie wpływ na status zatrudnienia absolwenta. Skalę zjawiska podejmowania pracy zarobkowej podczas studiów ukazano na rys. 2.

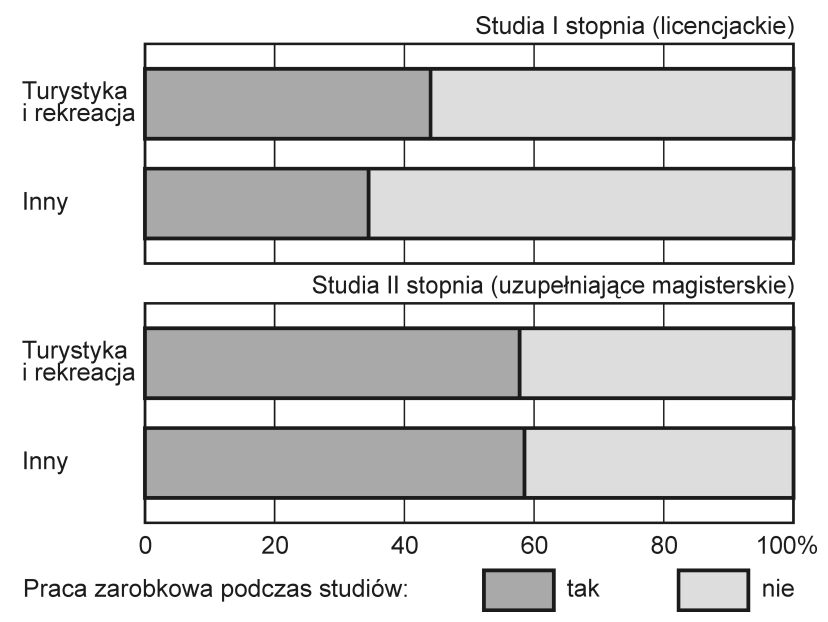

Rys. 2. Skala zjawiska pracy zarobkowej przez badanych absolwentów WNG UŁ podczas studiów z uwzględnieniem ich kierunku i rodzaju

Absolwenci TiR ogólem deklarowali pracę zarobkową $\mathrm{w}$ czasie studiów nieco częściej niż koledzy z innych kierunków studiów. Widać wyraźną różnicę w skali zatrudnienia między kierunkami TiR/Inny wśród studentów studiów I stopnia na Uniwersytecie Łódzkim (tab. 11).

Tab. 11. Forma zatrudnienia podczas studiów absolwentów WNG UŁ z uwzględnieniem kierunku studiów ${ }^{a}$

\begin{tabular}{|l|r|r|r|r|r|r|}
\hline \multirow{2}{*}{ Forma zatrudnienia } & \multicolumn{2}{|c|}{$\begin{array}{l}\text { Inny } \\
\text { kierunek }\end{array}$} & \multicolumn{2}{c|}{$\begin{array}{l}\text { Turystyka } \\
\text { i rekreacja }\end{array}$} & \multicolumn{2}{|c|}{ Ogółem } \\
\cline { 2 - 7 } & \multicolumn{1}{c|}{$N$} & \multicolumn{1}{c|}{$\%$} & \multicolumn{1}{c|}{$N$} & \multicolumn{1}{c|}{$N$} & $\%$ \\
\hline $\begin{array}{l}\text { Własna działalność } \\
\text { gospodarcza }\end{array}$ & 6 & 3,4 & 1 & 1,8 & 7 & 3,0 \\
\hline $\begin{array}{l}\text { Umowa o pracę } \\
\text { na pełen etat }\end{array}$ & 25 & 14,0 & 10 & 18,2 & 35 & 15,0 \\
\hline $\begin{array}{l}\text { Umowa o pracę } \\
\text { na część etatu }\end{array}$ & 32 & 18,0 & 1 & 1,8 & 33 & 14,2 \\
\hline $\begin{array}{l}\text { Umowa zlecenia } \\
\text { (w tym płatny staż) }\end{array}$ & 125 & 70,2 & 40 & 72,7 & 165 & 70,8 \\
\hline Umowa o dzieło & 22 & 12,4 & 4 & 7,3 & 26 & 11,2 \\
\hline Bez umowy & 34 & 19,1 & 10 & 18,2 & 44 & 18,9 \\
\hline Ogółem & 178 & 100,0 & 55 & 100,0 & 233 & 100,0 \\
\hline
\end{tabular}

Objaśnienie: ${ }^{a}$ - Odpowiedzi zebrano za pomocą pytania wielokrotnego wyboru. 
Studenci najczęściej pracowali na umowę zlecenie (w tym staż płatny), a najrzadziej wskazywali prowadzenie własnych firm. Mniejszy natomiast był odsetek absolwentów TiR, niż kolegów z innych kierunków pracujących na część etatu.

\section{ZATRUDNIENIE ABSOLWENTÓW ROK PO UKOŃCZENIU STUDIÓW}

Na pytanie: „Czy aktualnie Pani/Pan pracuje?” twierdząco odpowiedziało około $2 / 3$ respondentów. $W$ podziale na kierunki studiów najwyższy odsetek pracujących charakteryzował absolwentów TiR (rys. 3).

Widoczna jest różnica odsetka pracujących w zależności od rodzaju ukończonych studiów: udział pracujących absolwentów ze stopniem licencjata był znacznie mniejszy (ok. 40\%), niż z tytułem magistra

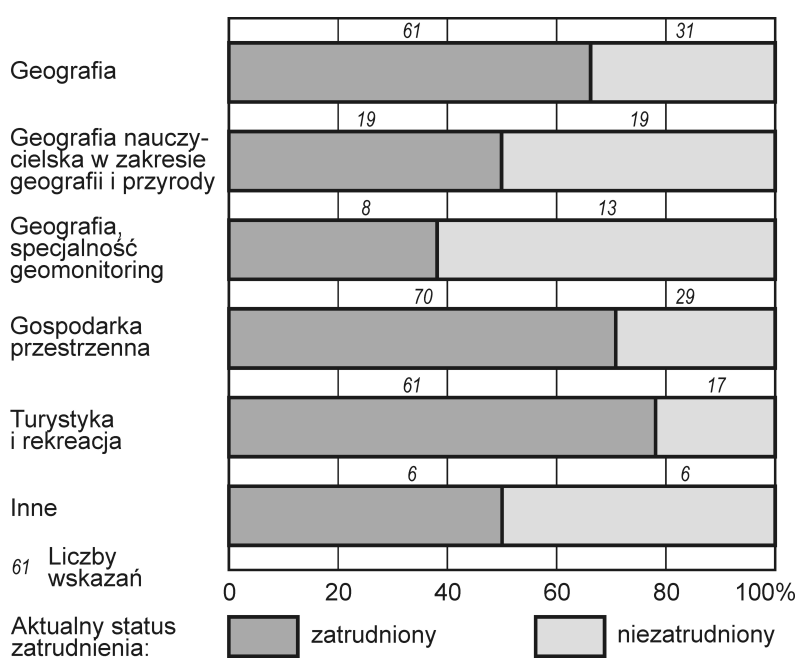

Rys. 3. Status zatrudnienia absolwentów WNG UŁ według kierunków studiów

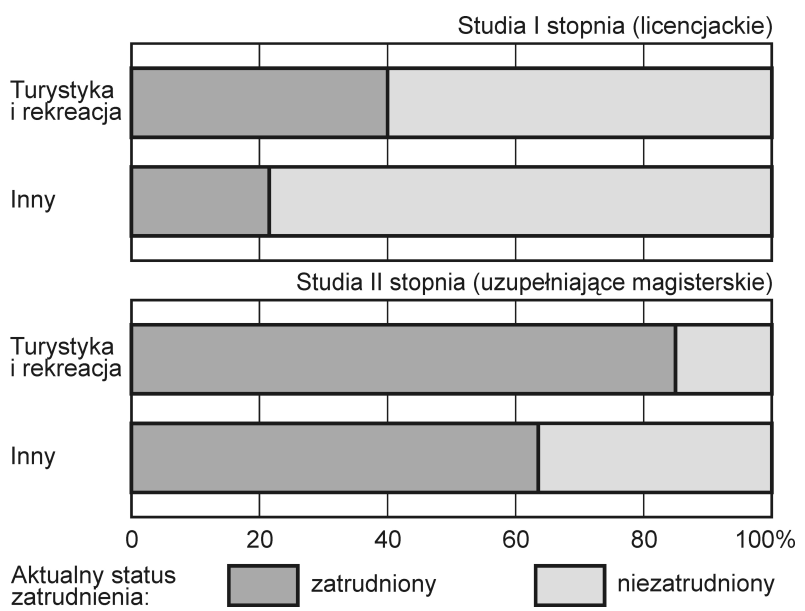

Rys. 4. Status zatrudnienia absolwentów WNG UŁ według kierunku i rodzaju studiów
(80,5\%). Wśród absolwentów TiR poziom zatrudnienia jest wyższy niż w przypadku wszystkich absolwentów innych łącznie kierunków także w podziale na rodzaj studiów, co przedstawiono na rys. 4 .

Znając skalę zatrudnienia absolwentów, można przejść do charakterystyki osób pracujących. Zapytano ankietowanych m.in. o liczbę miejsc, w których jednocześnie pracują. Absolwenci TiR częściej niż kończący inne kierunki wskazywali tzw. wielopracę. Wielopraca charakteryzuje pracowników port folio, czyli „osób, które świadczą pracę dla więcej niż jednego pracodawcy” (LIPIŃSKA-GROBELNY 2014, s. 9). Różnica w skali zjawiska wielkopracy widoczna jest także w podziale na absolwentów studiów I i II stopnia, co ukazano na rys. 5 .

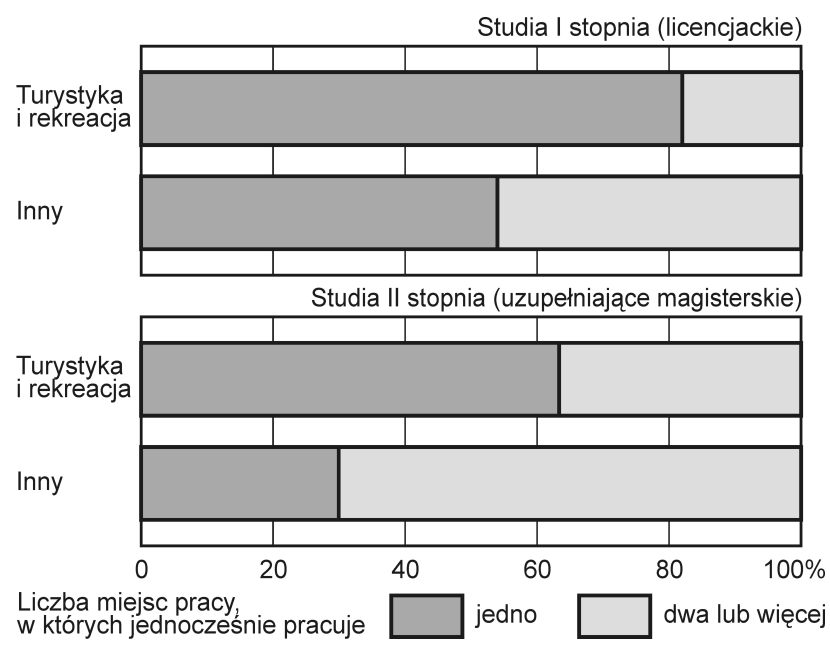

Rys. 5. Wielopraca absolwentów WNG UŁ według kierunku i rodzaju studiów

Ze względu na cel i zakres przedmiotowego artykułu oraz dużą liczbę kategorii w kolejnych przekrojach zrezygnowano $\mathrm{z}$ porównań między kierunkami i zajęto się tylko absolwentami TiR $(n=61)$. Mowa tu wyłącznie o osobach pracujących (por. rys. 3). Zachowano podział na rodzaj studiów z uwagi na występujące różnice między studiami I i II stopnia.

Absolwenci studiów I stopnia najczęściej udzielali odpowiedzi, że ich miesięczne zarobki brutto w chwili badania to mniej niż 1000 zł. Kończący studia II stopnia najczęściej wskazywali kategorię 1501-2000 zl, a nieco rzadziej 2501-3000 zł (rys. 6). Uwaga: na rys. 6, 7 i 8 skala liczbowa oznacza liczbę odpowiedzi. Należy pamiętać także, że liczebność grupy absolwentów studiów I stopnia była mniejsza niż II stopnia.

Ponad połowa absolwentów studiów I stopnia i około $2 / 3$ II stopnia uznało wykonywana pracę za zgodną ze swoim wykształceniem. W pierwszej z grup dominowała odpowiedź „raczej tak”, w drugiej „,zdecydowanie tak" (rys. 7). 


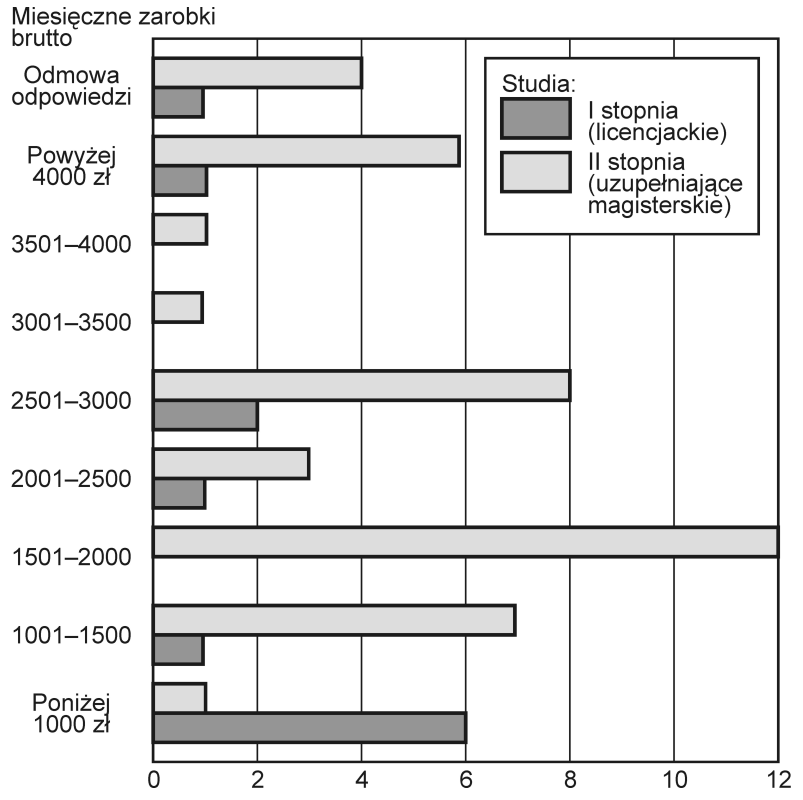

Rys. 6. Miesięczne zarobki brutto absolwentów TiR UŁ według rodzaju studiów

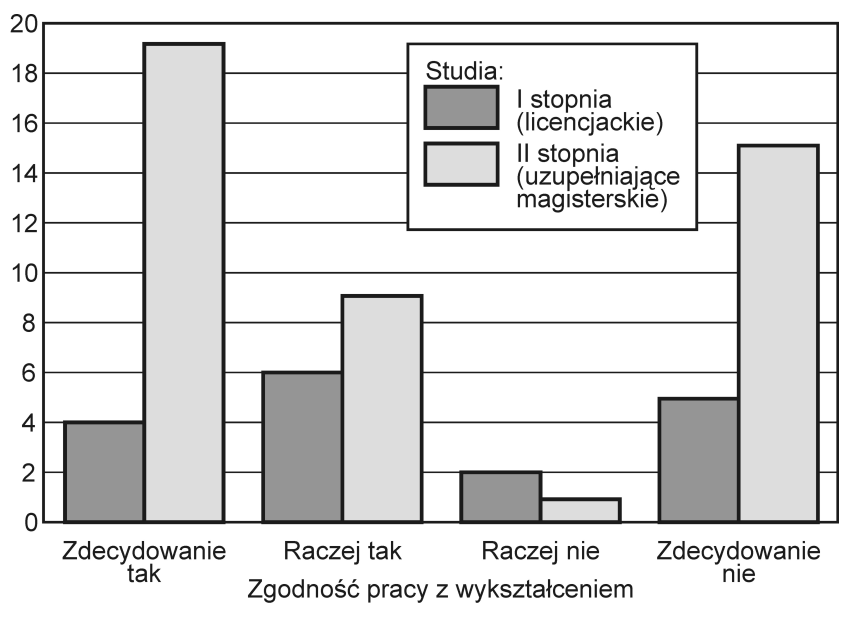

Rys. 7. Zgodność pracy z wykształceniem absolwentów TiR UŁ według rodzaju studiów

Warto zastanowić się jednak, jak respondenci rozumieją pytanie o zgodność pracy z wykształceniem, ponieważ pozornie zbliżona prośba o ocenę stopnia wykorzystywania $\mathrm{w}$ pracy wiedzy i kwalifikacji kierunkowych dała odmienne wyniki. Odpowiedzi „zdecydowanie - " i "raczej tak" wybrało odpowiednio niecała $1 / 3 \mathrm{i}^{1} 1 / 2$ absolwentów studiów I i II stopnia (rys. 8). Skrzyżowanie odpowiedzi wskazuje, że tylko respondenci wybierający możliwość „zdecydowanie nie” w pytaniu o zgodność pracy z wykształceniem, wskazywali wyłącznie negatywne odpowiedzi w przypadku pytania o wykorzystywanie w pracy wiedzy/kwalifikacji uzyskanych na studiach. Tym samym niektórzy absolwenci TiR uważają swą pracę za zgodną z wykształceniem i jednocześnie sądzą, że raczej nie wykorzystują w niej kierunkowej wiedzy czy kwalifikacji. Zdarzają się pojedyncze deklaracje odwrotne: że „praca raczej niezgodna z wykształceniem” i „raczej korzystają z kompetencji nabytych na studiach".

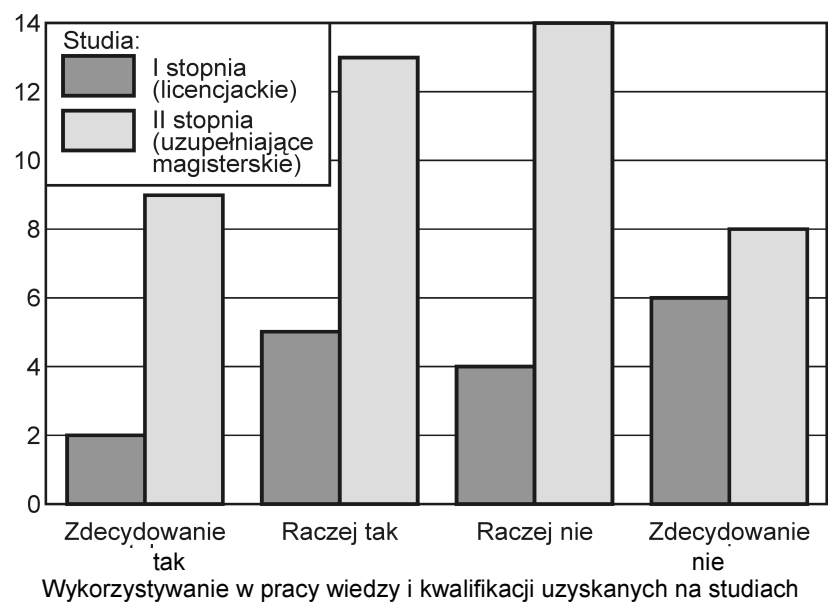

Rys. 8. Wykorzystywanie w obecnej pracy wiedzy i kwalifikacji uzyskanych na studiach przez absolwentów TiR UŁ według rodzaju studiów

\section{MODEL STATUSU ZATRUDNIENIA ABSOLWENTÓW}

Poszukiwania odpowiedzi na pytanie: „Od czego zależy status zatrudnienia absolwenta?" doprowadziły do skonstruowania modelu z użyciem regresji logistycznej. Zmienną celu był status zatrudnienia absolwenta w chwili badania: 0 - niezatrudniony, 1 - zatrudniony. Regresja logistyczna jest typową techniką modelowania dla zmiennej zależnej dychotomicznej „porażka/ sukces" (FIELD 2013, DANIELUK 2010, BEDYŃSKA, BRZEZICKA 2007).

W fazie eksploracji danych poszukiwano potencjalnych predyktorów, szukając zmiennych związanych ze zmienną celu (LAROSE 2006, s. 45-51). Zastosowano test niezależności $c h i^{2}$ dla zmiennej celu względem 23 zmiennych - pytań zadanych ogółowi respondentów (wyłączono pytania zadawane tylko pracującym bądź tylko niepracującym). Sześć zmiennych niezależnych, dla których wynik testu był istotny lub na granicy istotności statystycznej włączono do pierwszej wersji modelu. Zastosowano metodę wprowadzania (enter). Następnie wykonano model ostateczny, dodając pięć zmiennych niezależnych, dla których $\mathrm{w}$ wersji pierwszej uzyskano wynik istotny statystycznie. Tu także zastosowano metodę wprowadzania. Modelowanie wykonano dla $n=331$ absolwentów WNG, ponieważ u dziewięciu respondentów wystąpily pojedyncze braki odpowiedzi (item nonresponse) w analizowanych pytaniach.

$\mathrm{W}$ tab. 12 przedstawiono parametry zmiennych niezależnych ostatecznej wersji modelu. 
Tab. 12. Parametry predyktorów modelu regresji logistycznej

\begin{tabular}{|c|c|c|c|c|c|}
\hline \multicolumn{2}{|r|}{ Predyktor } & $B$ & $d f$ & $p$ & $\operatorname{Exp}(B)$ \\
\hline \multirow[t]{10}{*}{ Krok 1.} & Podstawowy kierunek studiów & 0,861 & 1 & 0,020 & 2,365 \\
\hline & Rodzaj studiów & 1,895 & 1 & 0,000 & 6,655 \\
\hline & Tryb studiów & $-1,867$ & 1 & 0,021 & 0,155 \\
\hline & Wybrane umowy - praca podczas studiów & 0,951 & 1 & 0,001 & 2,588 \\
\hline & Wielkość miejscowości (1) & 0,423 & 1 & 0,573 & 1,526 \\
\hline & Wielkość miejscowości (2) & $-0,136$ & 1 & 0,734 & 0,873 \\
\hline & Wielkość miejscowości (3) & 2,181 & 1 & 0,014 & 8,853 \\
\hline & Wielkość miejscowości (4) & 0,536 & 1 & 0,117 & 1,710 \\
\hline & Wielkość miejscowości & nie dotyczy & 4 & 0,047 & nie dotyczy \\
\hline & Stała & 0,785 & 1 & 0,375 & 2,193 \\
\hline
\end{tabular}

Wpływ wskazanych predyktorów na zmienną celu można interpretować za pomocą $\operatorname{Exp}(B)$, rozumianego jako iloraz szans (przy kontroli pozostałych predyktorów).

A. Zatem dla zastosowanych czterech predyktorów dychotomicznych:

1) podstawowy kierunek studiów: 0 - inny kierunek, 1 - TiR; szansa "bycia zatrudnionym” jest 2,4 razy wyższa w grupie absolwentów TiR niż dla absolwentów innych kierunków ujętych łącznie;

2) rodzaj studiów: 0 - I stopnia, 1 - II stopnia; szansa „bycia zatrudnionym” jest 6,7 razy wyższa w grupie absolwentów II stopnia niż dla kończących studia I stopnia;

3) tryb studiów: 0 - niestacjonarne, 1 - stacjonarne; szansa jest $6,5^{1}$ razy niższa dla absolwentów studiów stacjonarnych;

4) wybrane umowy - praca podczas studiów: 0 - pracujący $\mathrm{w}$ ramach własnej działalności gospodarczej lub w ramach umowy o dzieło, lub pracujący bez umowy, lub niepracujący; 1 - pracujący na umowę o pracę na cały etat, lub na część etatu, lub na umowę zlecenie ( $\mathrm{w}$ tym płatny staż). Takie rekodowanie formy zatrudnienia podczas studiów podyktowane zostało wynikami eksploracji danych - tylko dla form zgrupowanych pod kodem "1" uzyskano istotny statystycznie wynik testu niezależności $c h i^{2}$, a dodatnie wartości miary siły związku phi wskazywały na pozytywną zależność (NAWOJCZYK 2002, s. 223-224) między podejmowaniem podczas studiów pracy $\mathrm{w}$ ramach tych form zatrudnienia a "byciem zatrudnionym" rok po ukończeniu studiów; szansa „bycia zatrudnionym" jest 2,6 razy wyższa dla grupy o kodzie "1".

B. Oraz jednego predyktora jakościowego z pięcioma kategoriami (por. tab. 7):

Wielkość miejscowości zamieszkania; zmienną rekodowano na tzw. dummy variables, czyli zmienne dychotomiczne wskazujące na poszczególne kategorie: 0 - nie, 1 - tak. Takich zmiennych jest o jedną mniej niż kategorii, ponieważ jedna pozostaje domyślna; przyjmuje wartość "tak" wtedy, gdy wszystkie pozostałe dummy variables mają wartość „nie” (LAROSE
2006, s. 133). W tym przypadku jest to kategoria "wieś", która stanowi odniesienie do pozostałych, zatem:

1) szansa „bycia zatrudnionym" jest 1,5 raz wyższa dla absolwentów mieszkających w miastach do 10 tys. mieszkańców (niż dla wsi);

2) szansa jest 1,1 raz niższa dla miast od 10 do 100 tys. mieszkańców;

3) szansa jest 8,9 razy wyższa dla miast od 100 do 500 tys. mieszkańców ${ }^{2}$;

4) szansa jest 1,7 raz wyższa dla miast powyżej 500 tys. mieszkańców.

Model jest istotny statystycznie i średnio dopasowany do danych:

$-\operatorname{chi}^{2}(8)=100,82 ; p<0,001$.

- pseudo $R^{2}=0,26$ (Cox i Snell); 0,36 (Nagelkerke).

Trafność przewidywania (accuracy) statusu zatrudnienia wynosi ogólem $75,8 \%$ : 54,8\% poprawnych klasyfikacji "niezatrudniony” (specificity); 87\% "zatrudniony" (sensitivity). Tym samym za pomoca tego modelu trudniej przewidzieć brak zatrudnienia (tab. 13).

Większy błąd klasyfikacji statusu "niezatrudniony" uzyskano również $\mathrm{w}$ przywoływanej pracy D. Piróg. Poprawność zaklasyfikowania "niezatrudniony” wyniosła 75,6\%, zaś „zatrudniony” - 81,3\%; ogółem trafność przewidywania modelu Piróg dla grupy testowej to $78,5 \%$ (PIRÓG 2015, s. 166). Klasyfikacja jest zatem "lepsza", niż w modelu zaproponowanym w niniejszym artykule, szczególnie jeżeli mowa o niezatrudnionych. Zauważmy jednak, że zastosowano tam model znacznie bardziej złożony - użyto aż 28 predyktorów do modelowania 375 obserwacji (PIRÓG 2015, s. 161-162), zaś w niniejszym artykule pięciu predyktorów do 331 obserwacji. W przypadku bardziej skomplikowanego modelu Piróg można rozważyć zwiększenie liczby obserwacji bądź zmniejszenie liczby predyktorów (FIELD 2009, s. 222-223). Niemniej z uwagi na potencjał praktycznego zastosowania wyników tego rodzaju analiz we wsparciu studentów czy absolwentów poprawność klasyfikacji osób niezatrudnionych - a właściwie czynników ryzyka braku zatrudnienia - jest szczególnie ważna. 
Tab. 13. Macierz klasyfikacji modelu regresji logistycznej

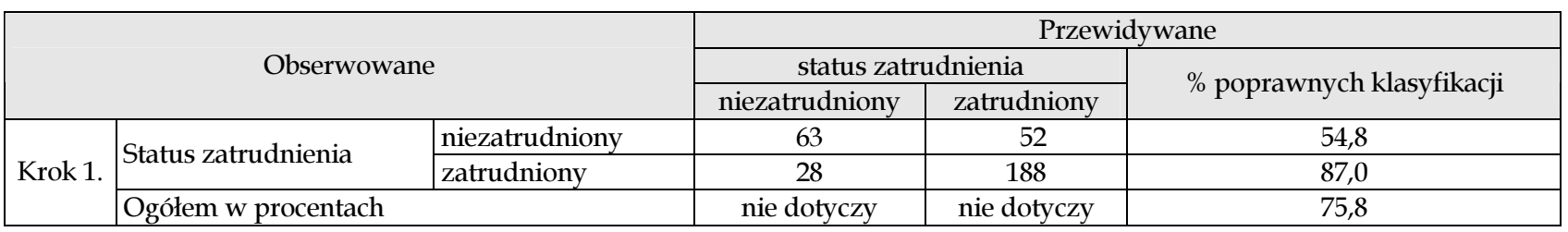

Warto zwrócić szczególną uwagę na zmienne, które $\mathrm{z}$ uwagi na wyniki analizy nie zostały włączone do zaproponowanego tu modelu, a wydawały się mieć pozytywny wpływ na karierę zawodową absolwenta.

Pierwszą z nich jest działalność w kołach naukowych podczas studiów. Dla tej zmiennej test niezależności zastosowany $\mathrm{w}$ fazie eksploracji był istotny statystycznie: $c h i^{2}(1,340)=4,37 ; p<0,05$. Ujemna wartość miary siły związku phi $=-0,13$ informuje o słabej zależności negatywnej (NAWOJCZYK 2002, s. 223-224) między podejmowaniem działalności w kołach naukowych a statusem zatrudnienia rok po ukończeniu studiów. Zależność ukazano w tab. 14: wśród osób deklarujących działalność w kołach naukowych odsetek osób pracujących był niższy, niż wśród niedeklarujących takiego działania.

Tab. 14. Status zatrudnienia absolwentów WNG UŁ z uwzględnieniem wcześniejszej działalności w kołach naukowych

\begin{tabular}{|l|r|r|r|r|}
\hline \multirow{2}{*}{$\begin{array}{c}\text { Aktualny status } \\
\text { zatrudnienia }\end{array}$} & \multicolumn{4}{|c|}{$\begin{array}{c}\text { Dodatkowe formy aktywności } \\
\text { podczas studiowania - działalność } \\
\text { w kołach naukowych }\end{array}$} \\
\cline { 2 - 5 } & \multicolumn{3}{|c|}{ tak } & \multicolumn{2}{c|}{ nie } \\
\cline { 2 - 5 } & $N$ & $\%$ & $N$ & $\%$ \\
\hline Zatrudniony & 23 & 52,3 & 202 & 68,2 \\
\hline Niezatrudniony & 21 & 47,7 & 94 & 31,8 \\
\hline Ogółem & 44 & 100,0 & 296 & 100,0 \\
\hline
\end{tabular}

Analiza pozostałych dodatkowych zajęć, o które pytano w ankietach (praktyki nieobligatoryjne; staż; wolontariat; działalność w organizacjach studenckich; studia, praktyki w ramach różnych programów wymiany studenckiej) za pomocą testu opisanego wyżej, nie wykazała związku ze zmienną celu. Nieistotny statystycznie wynik uzyskano także dla zgrupowanej zmiennej: "podejmowano jakiekolwiek z dodatkowych form aktywności".

\section{PODSUMOWANIE}

Za pomocą zaproponowanego modelu regresji logistycznej udało się trafnie przewidzieć status zatrudnienia absolwenta $\mathrm{w}$ około $3 / 4$ przypadków. Cztery z pięciu predyktorów to charakterystyki strukturalnoinstytucjonalne: wielkość jednostki osadniczej miejsca zamieszkania, rodzaj, tryb i kierunek ukończonych studiów. Jedyna charakterystyka behawioralna, jaka została włączona do modelu to podejmowanie pracy podczas studiów (w ramach konkretnych form zatrudnienia: cały etat, część etatu, umowa zlecenia - w tym płatny staż).

Zastanawiający jest fakt, że za pomocą zastosowanych narzędzi statystycznych nie stwierdzono, by związek z "byciem zatrudnionym" miały inne podejmowane w czasie studiów rodzaje aktywności. Skrajnie upraszczając, wniosek brzmi następująco: kto na studiach miał pracę, raczej będzie ją miał rok po ich ukończeniu. Na poparcie tej tezy dodajmy, że w omawianych badaniach prowadzonych przez Biuro Karier UŁ około $48 \%$ ogółu pracujących absolwentów WNG zadeklarowało, że kontynuują pracę podjętą w czasie studiów. Zidentyfikowana zależność może wskazywać na wartość zdobywania doświadczenia zawodowego w czasie studiów. Znaczenie takiego doświadczenia w dalszej karierze zawodowej podkreślają autorzy jakościowego studium poświęconego przygotowaniu studentów do pracy w branży wypoczynku, turystyki i rekreacji (LTR - Leisure, Recreation and Tourism). Badano zarówno pracujących od wielu lat profesjonalistów, jak i studentów; wszyscy badani profesjonaliści podkreślali duże znaczenie doświadczenia zawodowego w wejściu na rynek pracy w branży LTR (CHEN, GURSOY 2008, s. 34).

Interesujące są jeszcze dwie zidentyfikowane zależności z „byciem zatrudnionym”: rodzaj studiów i ich kierunek. Co do pierwszej jasne jest, że osoby konczące I stopień studiów raczej nie wchodzą w pełni na rynek pracy - rok po ukończeniu studiów pracowało około $40 \%$ badanych, a niemal wszyscy niepracujący deklarowali kontynuowanie nauki. Zależność drugą należy traktować ostrożnie. Choć atrakcyjne, błędne byłoby stwierdzenie: „Lepiej studiować TiR niż każdy z innych kierunków na WNG". Na potrzeby tego artykułu sztucznie zagregowano kierunki inne niż TiR, by uwypuklić różnice. Zatem zgodnie z lege artis wolno mówić, że szansa bycia zatrudnionym jest wyższa w grupie absolwentów TiR niż wśród absolwentów kierunku „zagregowanego".

Niewątpliwie na uzyskany tu model może mieć wpływ problem niereprezentatywności próby. Jeżeli 
próba miałaby być reprezentatywna dla kierunku studiów, który w danym roku kończy np. 100 osób, to należałoby poddać badaniu losowo wybranych 79 absolwentów tego kierunku ${ }^{3}$ (BABBIE 2003). Obecny proces zbierania zgód na udział $\mathrm{w}$ badaniu i sama realizacja badania praktycznie uniemożliwia takie postępowanie. Warto zatem dążyć do prostego zwiększania liczby zgód i odpowiedzi na badanie - zatem należy informować i promować te badania wśród studentów i pracowników UŁ.

Kończąc rozważania, należy zastanowić się nad zasadnością postawionego $\mathrm{w}$ tym artykule pytania. Jako zmienną celu przyjęto status zatrudnienia absolwenta rok po ukończeniu studiów, a zdarzenie „zatrudniony" potraktowano w kategorii sukcesu. Czy nie kryje się za tym założenie o celu kształcenia na uniwersytecie? Jeżeli tak, to cel kształcenia - ów sukces - osiąga się wtedy, gdy absolwent rok po studiach ma pracę. Założenie takie ma naturę niejako modernistyczną i neoliberalną: wyższe wykształcenie daje pracę, a praca traktowana jest jednoznacznie jako wartość. Cel kształcenia, a właściwie rola uniwersytetu traktowana jest jako pragmatyczna. Problem „uniwersytetu zaangażowanego" (uniwersytet zaangażowany... 2010) czy „świątyni wiedzy" (CZEŻOWSKI 1946) podnoszony w dyskusjach humanistów jest tu pominięty. Odchodzenie od funkcji założonej na rzecz funkcji rzeczywistej uniwersytetu uznawane było za rodzaj ogólnoświatowego trendu już 15 lat temu (KOBYLAREK 2002, s. 90); być może wyrazem tej tendencji są także zawarte $\mathrm{w}$ niniejszym artykule analizy.

Dodatkowo, czy rok po studiach to właściwy czas na „ewaluację"? A jeśli tak, to jak ocenić sytuację, w której absolwent pracuje tam, gdzie pracowal w czasie studiów? Bez wątpienia pole to wymaga pogłębionej analizy. Liczni autorzy podejmujący problematykę losów absolwentów szkół wyższych akcentują potrzebę badania sytuacji na rynku pracy (KRUK, red. 2007, SUCHORAB 2015), badania indywidualnych charakterystyk psychospołecznych - głównie szeroko pojętych kompetencji (ROGOZIŃSKA-PAWEECZYK, MAJEWSKI, red. 2011, WIECHETEK, TALIK, red. 2014), a także makroprocesów społeczno-ekonomicznych (ZIELIŃSKA 1997, SMARZEWSKA 2016). Podobnie $\mathrm{w}$ omawianym modelu Piróg: użyte 28 predyktorów to zarówno charakterystyki psychologiczne, behawioralne, jak i plany czy opinie respondentów (PIRÓG 2015, s. 161). Wydaje się, że w podobnych analizach warto brać pod uwagę różnego rodzaju zmienne, a także korzystać ze studiów jakościowych. Należy rozważyć także badania nastawione na rozpoznanie realizacji funkcji założonej uniwersytetu.

\section{PRZYPISY}

${ }^{1}$ Ponieważ $\operatorname{Exp}(B)<1$, iloraz szans wygodniej prezentować jako $1 / \operatorname{Exp}(B): 1 / 0,155=6,45$.

${ }^{2}$ Wyłącznie dla tej wielkości miejsca zamieszkania uzyskano istotną statystycznie różnicę względem kategorii odniesienia; przy tym w modelu "cała" zmienna jest istotna statystycznie, o czym informuje $p<0,05 \mathrm{w}$ wierszu, gdzie liczba stopni swobody $d f=4$ (por. tab. 11).

${ }^{3}$ Przy poziomie ufności 95\%, wielkości frakcji 0,5 i błędzie maksymalnym $5 \%$.

\section{BIBLIOGRAFIA}

BABBIE E., 2003, Badania spoteczne w praktyce, Wyd. Naukowe PWN, Warszawa, 659 ss.

BEDYŃSKA S., BRZEZICKA A. (red.), 2007, Statystyczny drogowskaz Praktyczny poradnik analizy danych w naukach społecznych na przykładach z psychologii, Wyd. SWPS "Academica”, Warszawa.

BRZEZIŃSKI J., 2003, Metodologia badań psychologicznych, Wyd. Naukowe PWN, Warszawa, 684 ss.

CHEN B.T., GuRSOY D., 2008, Preparing Students for Careers in the Leisure, Recreation and Tourism Field, "Journal of Teaching in Travel \& Tourism", 7, 3, s. 21-41.

CZEŻOWSKI T., 1946, O uniwersytecie $i$ studiach uniwersyteckich, Księgarnia Naukowa T. Szczęsny i S-ka, Toruń, 67 ss.

DANIELUK B., 2010, Zastosowanie regresji logistycznej w badaniach eksperymentalnych, „Psychologia Społeczna”, 5, 2-3 (14), s. 199-216.

FIELD A., 2009, Discovering Statistics Using SPSS, SAGE Publications Ltd., London, 821 ss.

KOBYLAREK A., 2002, Uniwersytet - zarys idei podstawowej, „Nauka i Szkolnictwo Wyższe", 1, s. 90-100.

KRUK M. (red.), 2007, Studia $i$ co dalej... Sytuacja studentów na rynku pracy, Uniwersytet w Białymstoku, Białystok, 214 ss.

LAROSE D.T., 2006, Odkrywanie wiedzy z danych. Wprowadzenie do eksploracji danych, Wyd. Naukowe PWN, Warszawa, 227 ss.

LiPIŃSKA-GROBELNY A., 2014, Zjawisko wielopracy. Psychologiczne uwarunkowania i konsekwencje, Wyd. Uniwersytetu Łódzkiego, Łódź, 247 ss.

LISZEWSKI S., 2010, Nauka czy nauki o turystyce (artykut dyskusyjny), ,Turyzm", 20/2, s. 37-45.

NAWOJCZYK M., 2002, Przewodnik po statystyce dla socjologów, SPSS Polska, Kraków, 301 ss.

PAŁASZ L., 2004, Ksztatcenie oraz losy absolwentów, Wyd. Akademii Rolniczej w Szczecinie, Szczecin, 140 ss.

PIRÓG D., 2015, Przechodzenie absolwentów studiów geograficznych na rynek pracy. Proces, czynniki, predykcja, Wyd. Naukowe UP, Kraków, 266 ss.

ROGOZIŃSKA-PAWEECZYK A., MAJEWSKI D. (red.), 2011, Absolwent na rynku pracy, Wyd. Uniwersytetu Łódzkiego, Łódź, 233 ss.

SMARZEWSKA A., 2016, Bezpieczeństwo edukacyjne absolwentów szkół wyższych, Wyd. Państwowa Szkoła Wyższa JPII, Biała Podlaska, 160 ss.

SUCHORAB A., 2015, Wybory edukacyjno-zawodowe w biografiach studentów na tle wyzwań wspótczesnego rynku pracy, Wyd Naukowe Wyższej Szkoły Informatyki i Zarządzania im. Profesora T. Kotarbińskiego, Olsztyn, 452 ss.

SZCZEPAŃSKI J., 1963, Socjologiczne zagadnienia wyższego wyksztatcenia, Państwowe Wyd. Naukowe, Warszawa, 367 ss 
TALIK W., WIECHETEK M. (red.), 2014, Kwestionariusz istotnych kompetencji w poszukiwaniu zatrudnienia (KIK-PZ), OIC Poland, Lublin, 129 ss.

Uniwersytet zaangażowany. Przewodnik krytyki politycznej, 2010, Zespół Krytyki Politycznej, Wyd. Krytyki Politycznej, Warszawa, 352 ss.

ZARZECKI M., BORNE-JANUŁA H., JAROSZEK K., PUCHALSKA K., PIOTROWSKA P., NOISZEWSKI Ł., 2010, Losy absolwentów szkót i uczelni ksztatcacych kadry dla turystyki, Ministerstwo Sportu i Turystyki, Warszawa, 323 ss.; https://www.msit.gov.pl/ download/1/4285/w2010f2ef.pdf; 05.07.2017.
ZIELIŃSKA M., 1997, Kariery zawodowe absolwentów wyższej uczelni, Lubuskie Towarzystwo Naukowe, Zielona Góra, 206 ss.

http:// biurokarier.uni.lodz.pl/projekty-biura-karier/monitoro wanie-karier-absolwentow/; 23.03.2017.

http://ela.nauka.gov.pl/includes/pdf/opis_raportow.pdf; 4.07 . 2017.

https://kariera.pracuj.pl/rozmowa_kwalifikacyjna/5-powodowdla-ktorych-warto-isc-na-staz/; 21.03.2017.

Podziękowanie

Autor dziękuje za udostępnienie danych z badań "Monitorowanie karier zawodowych absolwentów UŁ" Dyrektorowi Centrum Karier i Wspótpracy z Pracodawcami, Panu Doktorowi Dariuszowi Koperczakowi.

Artykuł wpłyną: 22 kwietnia $2017 \mathrm{r}$. Zaakceptowano do druku: 28 maja $2017 \mathrm{r}$. 